\title{
Growth, mortality and production of organic matter by a rocky intertidal population of Mytilus edulis in the Quoddy Region of the Bay of Fundy
}

\author{
J. P. A. Gardner*, M. L. H. Thomas \\ Division of Sciences, University of New Brunswick, PO Box 5050, Saint John, New Brunswick E2L 4L5, Canada
}

\begin{abstract}
A population of Mytilus edulis is described which is numerically dominated by young $(<2$ yr old) individuals. Growth within this population is indeterminate, i.e. no maximum shell length is attained throughout the realized life span. Predation pressure, principally by Carcinus maenas and Asterias vulgaris, results in a population mortality rate of $42 \%$ in a 6 mo period and also probably prevents growth from being determinate. The partitioning of organic matter between shell and body growth is discussed in connection with the cycling of energy within the ecosystem of the rocky intertidal zone.
\end{abstract}

\section{INTRODUCTION}

The blue or common mussel Mytilus edulis is an important member of the communities which typify exposed rocky shores (Suchanek 1978). M. edulis usually dominates the mid-littoral zone, especially where wave action is highest and slope is steep (Stephenson \& Stephenson 1949). However, in the Bay of Fundy (Canada), and particularly the Quoddy Region, the mid-littoral zone is dominated by fucoid algae, principally the knotted wrack Ascophyllum nodosum, irrespective of wave action (Thomas et al. 1983). As a consequence, both the size and distribution of $M$. edulis within the Bay are restricted. Nevertheless, population densities are still high and contribute significantly to the total biomass and secondary production of the area.

Previous work on the mussel within the Bay (Mossop 1922. Newcombe 1935) concentrated on growth rate determinations. Consequently, little is known about the partitioning of energy between shell and tissue growth. Although the organic matter content of shell may be small, the total amount of organic matter invested in such non-living matter may be great by virtue of the considerable weight of shell within a

\footnotetext{
- Present address: Department of Genetics, University College of Swansea, Singleton Park, Swansea SA2 8PP, United Kingdom
}

mussel population (Dare 1976). As such, the shell may represent a substantial percentage of the annual production of a mussel population (Kuenzler 1961, Paterson 1982, Hawkins \& Bayne 1985). It is important to understand how energy is partitioned between shell and tissue growth because this not only affects the physiological state of the mussel (energy for shell growth is obviously unavailable for routine metabolism, gametogenesis, etc.) but it also affects the general cycling of energy within the ecosystem as a whole. The rates of incorporation of radioactively labelled $\mathrm{C}$ and $\mathrm{N}$ into various soft tissues vary according to both season and tissue type, whilst the relative incorporation rates into shell are similar, regardless of season, but greatest in absolute terms during the summer (Hawkins \& Bayne 1985). This timing of maximal $\mathrm{C}$ and $\mathrm{N}$ incorporation into the shell is coincident with the timing of maximum food availability and is related to the ingestion of inorganic silt, but not necessarily organic particles such as algal cells (Winter 1976). The cumulative effect of seasonal variation in both exogenous factors (e.g. organic and inorganic particle concentrations) and endogenous factors (e.g. absorption rate and maintenance requirements) thus plays a critical role in determining not only the time-averaged optimization of energy directed to the production of organic matter as shell or tissue (Hawkins et al. 1985), but also to the cycling of energy within the rocky intertidal habitat. Energy directed towards body tissue growth is immedi- 
ately available as food to predators, whereas that directed towards shell growth will only become available to other trophic levels after a considerably longer period.

This study was undertaken to estimate the growth of an intertidal population of Mytilus edulis, to examine the partitioning of organic matter between tissue and shell growth and to assess the potential for the transfer of this growth, as food, to the cycling of energy within the ecosystem of the rocky intertidal region.

\section{MATERIALS AND METHODS}

The study area was situated at Welchs Cove, in the Bay of Fundy, Canada, approximately $50 \mathrm{~km} \mathrm{SW}$ of Saint John and within the Quoddy Region of the Bay. The Mytilus edulis population studied was located $0.15 \mathrm{~m}$ above mean low water of spring tides. The study period extended from mid-July to mid-December 1985. This encompassed the main period of population change, since spat settlement is well advanced by July (Battle 1932) and growth normally ceases by December (Newcombe 1935).

Samples of the mussels were collected by random $0.01 \mathrm{~m}^{2}$ quadrat sampling on $19 \mathrm{Jul}(\mathrm{n}=2156$ mussels collected) and $10 \mathrm{Dec}(\mathrm{n}=1248), 1985$. During each sampling period five $0.01 \mathrm{~m}^{2}$ quadrats of mussels were collected, care being taken to remove every mussel within each quadrat. Upon return to the laboratory each mussel was cleaned and measured for shell length

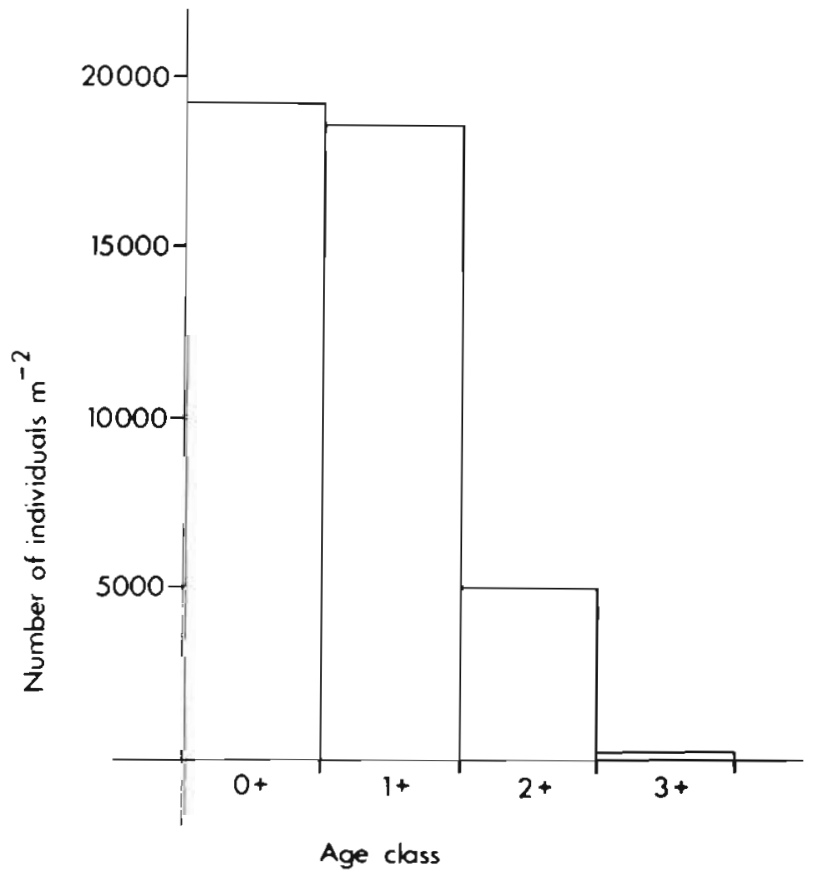

Fig. 1. Mytilus edulis. Number of individuals $\mathrm{m}^{-2}$ per cohort in July 1985

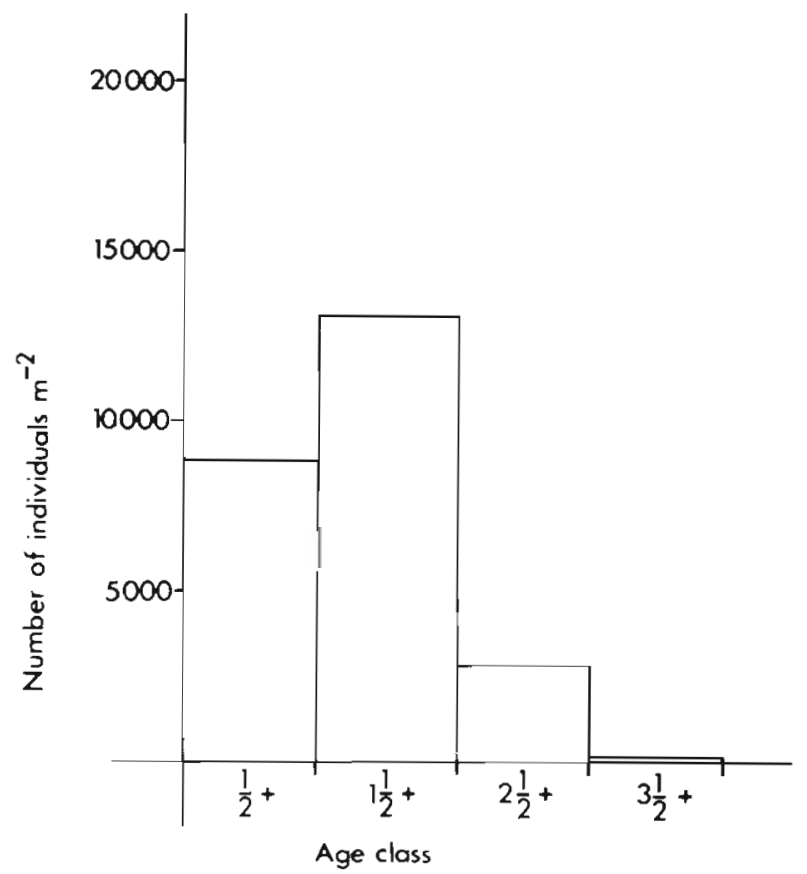

Fig. 2. Mytilus edulis. Number of individuals $\mathrm{m}^{-2}$ per cohort in December 1985

(the maximum distance between umbo and ventral margin) using vernier calipers accurate to $0.1 \mathrm{~mm}$ $( \pm 0.05)$ to estimate the length-frequency distribution. Cohort position was estimated by use of the Harding method (1949). Body tissue was dissected from the valves and both body tissue and shell were dried for $24 \mathrm{~h}$ at $90^{\circ} \mathrm{C}$ in a forced air oven, then weighed to determine dry body weight and dry shell weight. Body ash, body organic matter (BOM; = ash free body tissue), shell ash and shell organic matter (SOM) contents were determined by heating the dry body and shell in a muffle oven for $24 \mathrm{~h}$ at $450^{\circ} \mathrm{C}$. At this temperature there is no loss of $\mathrm{CO}_{2}$ from the $\mathrm{CaCO}_{3}$ of the shell, a common source of error in SOM determinations (Jørgensen 1976). Weights were measured to the nearest $0.1 \mathrm{mg}$. A microbomb calorimeter (Phillipson 1964) was used to estimate the calorific value per gram of ash free dry body tissue, to allow subsequent estimation and comparison of the calorific value of tissue and shell production, and the partitioning of energy between tissue and shell growth.

\section{RESUITS}

At the time of sampling in July, the population was composed of 4 age classes with cohort peaks occurring at $3,14,10$ and $17 \mathrm{~mm}$. The population was numerically dominated by young individuals, the newly settled spat $(0+$ cohort $)$ and the survivors of the previous years' settlement $(1+)$ cohort constituting $88 \%$ of the 
Table 1. Mytilus edulis. Change in population density by cohort, July and December 1985

\begin{tabular}{|c|c|c|c|c|}
\hline \multirow[b]{2}{*}{ Cohort } & \multirow{2}{*}{$\begin{array}{l}\text { July } \\
\text { No. of } \\
\text { ind } \mathrm{m}^{-2}\end{array}$} & \multicolumn{2}{|c|}{ December } & \multirow[b]{2}{*}{$\begin{array}{c}\% \\
\text { decrease }\end{array}$} \\
\hline & & Cohort & $\begin{array}{l}\text { No. of } \\
\text { ind } \mathrm{m}^{-2}\end{array}$ & \\
\hline $0+$ & 19320 & $1 / 2+$ & 8840 & 54.24 \\
\hline $1+$ & 18620 & $1^{1 / 2+}$ & 13100 & 29.65 \\
\hline $2+$ & 4980 & $21 / 2+$ & 2940 & 42.97 \\
\hline \multirow[t]{2}{*}{$3+$} & 200 & $3^{1 / 2}+$ & 180 & 10.00 \\
\hline & $\Sigma=\overline{43120}$ & & $=\overline{24960}$ & 42.12 \\
\hline
\end{tabular}

Table 2. Mytilus edulis. Change in mean population shell length between July and December 1985

\begin{tabular}{|lcc|}
\hline & July & December \\
\hline Mean shell length $(\mathrm{mm})$ & 9.612 & 14.619 \\
Standard deviation & 6.572 & 7.544 \\
Sample size & 2156 & 1248 \\
\hline
\end{tabular}

population (Fig. 1). By December all 4 cohorts had suffered considerable reduction in numbers (Fig. 2), the most notable reduction (54\%) being that of the new recruits to the population. However, despite this reduction the numerical dominance of the population by the younger individuals remained, and the $1 / 2+$ and $1 \frac{1 / 2}{2}$ cohorts still constituted $88 \%$ of the population (Table 1). By December, cohort peaks had shifted to 6 , 18,25 and $31 \mathrm{~mm}$ respectively, as a result of the growth of each cohort. Table 2 shows the mean increase in shell length of the population for the 5 mo period, the difference in mean shell lengths being statistically significant $(p<0.001)$.

A plot of the average ontogenetic growth curve (Cerrato 1980) calculated from the mean shell lengths of both the July and December cohorts is shown in Fig. 3. The line itself is not a true sigmoid curve as there is no decrease in growth rate with age. This is confirmed by regression analysis for the final 6 points of the data which indicates an almost completely linear relation between shell length and age, for both logarithmically transformed and untransformed data. The regression equations are:

$$
\begin{aligned}
& \text { age }(\mathrm{yr})=-1.082+0.148 \text { shell length }(\mathrm{mm}) \\
& (\mathrm{n}=6, \mathrm{r}=0.995, \mathrm{p}<0.001) \\
& \text { and } \\
& \log _{\mathrm{e}} \text { age }(\mathrm{yr})=-4.135+1.579 \log _{\mathrm{e}} \text { shell length }(\mathrm{mm}) \\
& (\mathrm{n}=6, \mathrm{r}=0.993, \mathrm{p}<0.001)
\end{aligned}
$$

Thus, growth at this site is indeterminate, continuing throughout the entire life span.

Table 3 shows the losses by cohort and for the population as a whole. Losses are inversely proportional to

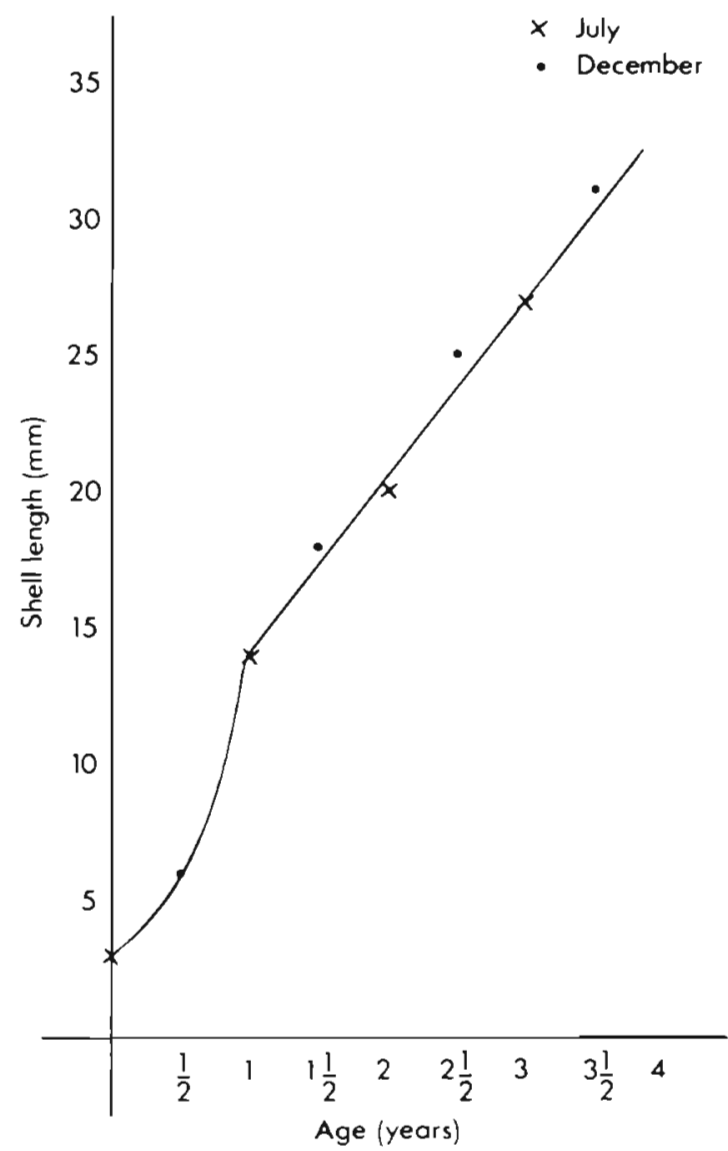

\begin{tabular}{|c|c|c|c|c|}
\hline $\begin{array}{l}\text { July } \\
\text { cohorts }\end{array}$ & $\begin{array}{l}\text { December } \\
\text { cohorts }\end{array}$ & $\begin{array}{l}\text { Cohort } \\
\text { mortality } \\
\text { (no. of ind } \\
\mathrm{m}^{-2} \text { ) }\end{array}$ & $\begin{array}{c}\text { Cohort } \\
\text { mortality } \\
\text { as } \% \text { of July } \\
\text { cohort density }\end{array}$ & $\begin{array}{c}\text { Cohort } \\
\text { mortality } \\
\text { as \% of July } \\
\text { population } \\
\text { density }\end{array}$ \\
\hline $0+$ & $1 / 2+$ & 10480 & 54.24 & 24.30 \\
\hline $1+$ & $11 / 2+$ & 5520 & 29.65 & 12.80 \\
\hline $2+$ & $2^{1 / 2}+$ & 2140 & 42.97 & 4.96 \\
\hline \multirow[t]{2}{*}{$3+$} & $3^{1 / 2}+$ & 20 & 10.00 & 0.05 \\
\hline & & $\Sigma=\overline{18160}$ & - & $\Sigma=\overline{42.11}$ \\
\hline
\end{tabular}

Fig. 3. Mytilus edulis. Ontogenetic growth curve calculated from data of July and December 1985

Table 3. Mytilus edulis. Mortality rates by cohort between July and December 1985

age. It was not possible to differentiate in the field between mortality and emigration, but within a mussel bed, immigration and emigration are usually considered to be equal.

Estimates of the mortality and survival rates of the population at the times of sampling can be obtained according to Ricker (1975). The calculated mortality and survival rates for July are 0.7776 and 0.2224 respectively; for December the corresponding values 
are 0.7331 and 0.2669 respectively. Ricker (1975) notes that if the value of $Z$ is the slope of a straight line then the mortality rate is constant. The lines calculated from Fig. 4 for July and December respectively are:

$$
\begin{aligned}
& \log _{\mathrm{e}} \hat{\mathrm{N}}_{\mathrm{t}}=10.633-1.593 \text { age }(\mathrm{yr}) \\
& (\mathrm{n}=4, \mathrm{r}=0.903, \mathrm{p}<0.05) \\
& \text { nd } \\
& \log _{\mathrm{e}} \hat{\mathrm{N}}_{\mathrm{t}}=10.570-1.321 \text { age }(\mathrm{yr}) \\
& (\mathrm{n}=4, \mathrm{I}=0.881, \mathrm{p}<0.05)
\end{aligned}
$$

hence $\mathrm{Z}$ in both cases is calculated from a straight line and the mortality rate in July and in December is constant throughout the population.

A comparison of body tissue, BOM, body ash, dry shell, SOM and shell ash weight per unit area between July and December shows that 5 of these 6 components of growth increased (Table 4 ) in spite of a $42 \%$ rate of population mortality (Table 3 ), but associated with an increase in the population's mean shell length of $52 \%$ (Table 2). The most significant change is the increase of $120 \%$ in dry shell weight $\mathrm{m}^{-2}$, accompanied by a $150 \%$ increase in the weight of shell ash material. The amount of organic matter in the shell decreased from $17.02 \%$ in July to $6.40 \%$ in December. The 2 components of dry body tissue, BOM and body ash, both increased (16 and $13 \%$ respectively) resulting in a $17 \%$ increase in dry body tissue weight between July and December. Although biomass increased by $104 \%$ from July to December the total amount of organic matter, i.e. BOM plus SOM, decreased by $0.5 \%$, small enough for the total amount of organic matter to be considered to have remained constant. However, the percentage contribution of the components changed. In July BOM made up $49.32 \%$, but by December this increased to $57.69 \%$. There was therefore a shift in the distribution of organic matter between the shell and body material within the population in the space of $6 \mathrm{mo}$, probably associated with the onset of gametogenesis in late November and December (Battle 1932).

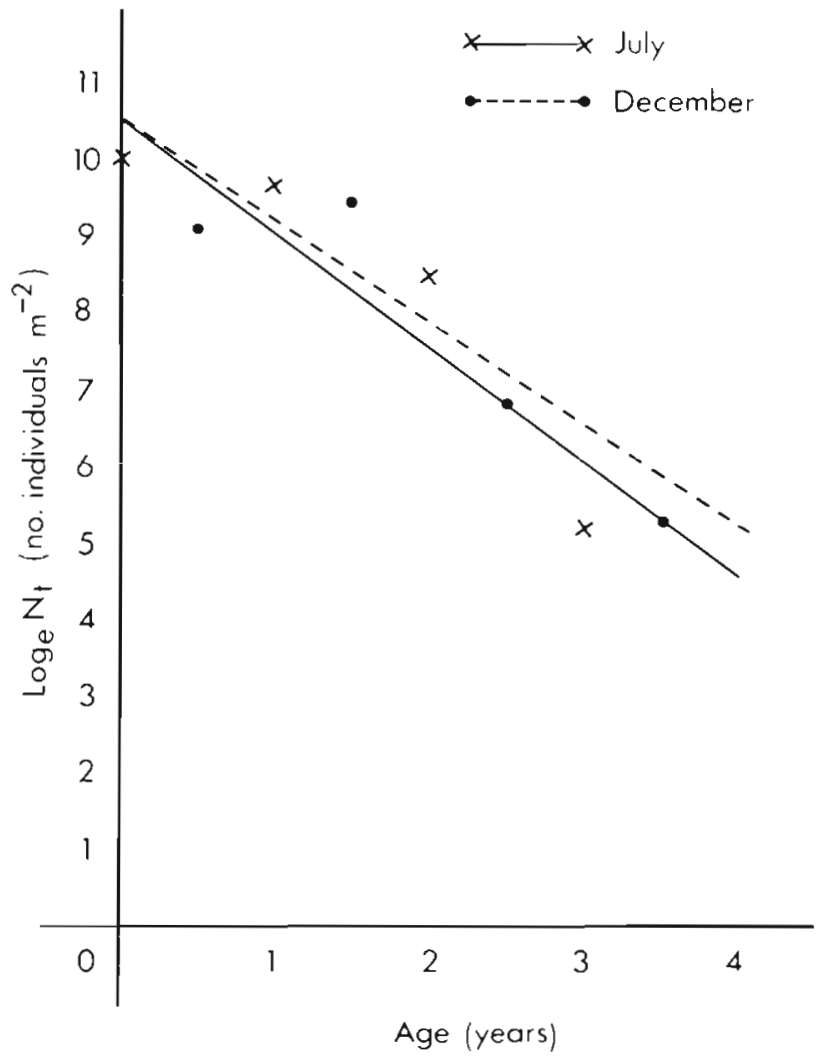

\begin{tabular}{|c|c|c|c|c|}
\hline \multirow[t]{2}{*}{ Parameter } & \multicolumn{2}{|c|}{ July } & \multicolumn{2}{|c|}{ December } \\
\hline & $\left(\mathrm{g} \mathrm{m}^{-2}\right)$ & $\left(\mathrm{kcal} \mathrm{m}^{-2}\right)$ & $\left(g \mathrm{~m}^{-2}\right)$ & $\left(\mathrm{kcal} \mathrm{m}^{-2}\right)$ \\
\hline Dry body tissue & $310.0 .3^{a}$ & - & 362.988 & - \\
\hline Body ash & 54.943 & - & 62.084 & - \\
\hline $\mathrm{BOM}$ & 242.068 & $1198.237^{b}$ & 281.667 & 1394.252 \\
\hline Dry shell material & 1461.379 & - & 3234.968 & \\
\hline Shell ash & 1210.389 & - & 3036.915 & - \\
\hline SOM & 248.683 & $1233.768^{c}$ & 206.610 & 1022.720 \\
\hline $\mathrm{SOM}+\mathrm{BOM}$ & 490.751 & 2432.004 & 488.277 & 2416.971 \\
\hline $\begin{array}{l}\text { Biomass (dry shell plus dry } \\
\text { body matter) }\end{array}$ & 1771.392 & - & 3597.956 & - \\
\hline Dry body wt: dry shell wt. & $1: 4.714$ & & $1: 8.912$ & \\
\hline Body ash wt:BOM & $1: 4.406$ & & $1: 4.537$ & \\
\hline BOM:SOM & $1: 1.027$ & & $1: 0.734$ & \\
\hline \multicolumn{5}{|c|}{$\begin{array}{l}\text { a Values calculated for population from regression analysis of } 30 \text { individuals } \\
\text { a } 1 \mathrm{~g} \text { ash free dry wt }=4.95 \mathrm{kcal} \text {, determined by calorimetry } \\
\text { " Protein conversion value (SOM is largely protein; Dare } 1976 \text { ) }\end{array}$} \\
\hline
\end{tabular}

Fig. 4. Mytilus edulis. Plot of $\log _{e}$ abundance against year class for July and December 1985

Table 4. Mytilus edulis. Production of organic matter and its calorific value in July and December 1985 
Calculation of the secondary production and P:B ratio of this population for the period July to December 1985, using the method of Crisp (1971), gives values of $2.901 \mathrm{~g}$ dry weight $\mathrm{m}^{-2} \mathrm{~d}^{-1}$ and 0.716 respectively.

\section{DISCUSSION}

The annual rates of cohort growth obtained in this study (Fig. 3) are less than those estimated by Mossop (1922) for Mytilus edulis within the Quoddy. This might be explained by the great variability in growth exhibited by molluscan populations, not only between sites but also within sites and within similar age classes (Wilbur \& Yonge 1964, Seed 1969, 1973, Bayne 1976, Dare 1976). Mossop (1922) noted that mean annual growth increments decreased with increasing age, suggesting that growth was determinate in the population that she studied.

Seed (1980) points out that growth in many bivalve populations may not be determinate, at least over their realized life span. Growth is likely to be indeterminate in the Welchs Cove mussel population because of the high level of predation typically associated with a low shore position (Seed 1969). Hence individuals of this population do not survive long enough to display determinate growth. The 2 major predators of Mytilus edulis at the study site are the shore crab Carcinus maenas and the starfish Asterias vulgaris, both of which are very abundant. Elsewhere, both these species have been shown to be responsible for considerable mussel mortality (Newcombe 1935, Reynolds 1969, Dare 1976).

The organic matter content of shell rarely exceeds $10 \%$ by weight in molluscan species (Wilbur \& Saleuddin 1983). In July at Welchs Cove, the SOM content of the shell material was $17 \%$ and by December this value had decreased to $6.4 \%$. When compared with other SOM estimates, e.g. $8 \%$ for Mytilus californianus (Fox \& Coe 1943), 11 and $5.5 \%$ for the ribbed mussel Geukensia demissus (Kuenzler 1961, Jørgensen 1976, respectively) and $3 \%$ for $M$. edulis (Thompson 1984), the SOM content of $M$. edulis within the Quoddy is high.

The energetics of shell formation are poorly known (Wilbur \& Saleuddin 1983), but it has been previously assumed that approximately $30 \%$ of the total energy of growth (including respiration) is required for shell deposition (Jørgensen 1976). Organic matter invested in shell production by Mytilus edulis within the Quoddy is considerable, amounting to $50.7 \%$ of the total organic matter of growth in July and $42.3 \%$ in December, compared to $35 \%$ for both the ribbed mussel Aulacomya ater (Griffiths \& King 1979) and 3 species of freshwater bivalve (Paterson 1982). However, such estimates are conservative because these values do not take into account the energy necessary for active ion transport, metabolic steps in the synthesis of SOM or the secretion of organic compounds by the mantle epithelium (Wilbur \& Saleuddin 1983).

The estimates of the calorific value of the organic matter of both body and shell material at Welchs Cove are based upon a value of $4.95 \mathrm{kcal} \mathrm{g}^{-1}$ ash free body tissue, which agrees well with other such estimates which range from 4.74 to $6.42 \mathrm{kcal} \mathrm{g}^{-1}$ ash free body weight (Winberg 1971, Milne \& Dunnet 1972, Dare \& Edwards 1975). The estimates of 2432 and $2417 \mathrm{kcal} \mathrm{m}^{-2}$ of total organic matter for July and. December respectively (Table 4 ), show that the calorific value of matter available both to predators and the decomposer chain is high, and that it is comparatively constant within the period of study.

Acknowledgements. The authors gratefully acknowledge the help of Donna Baxter, Rachel Girling, Wilfred Morris, Doug Tremblay and Mrs V. Winslow in the preparation of this paper. Financial support was provided by a Natural Sciences and Engineering Research Council of Canada operating grant to M. L. H. T

\section{LITERATURE CITED}

Battle, H. (1932). Rhythmical sexual maturity and spawning of certain bivalve mollusks. Contr. Can. Biol. Fish. N.S. 7: $257-276$

Bayne, B. L. (1976). Marine mussels. International Biological Programme Handbook No. 10. Cambridge Univ. Press

Cerrato, R. M. (1980). Demographic analysis of bivalve populations. In: Rhoads, D. C., Lutz, R. A. (ed.) Skeletal growth of aquatic organisms. Plenum Press, New York, p. 417-468

Crisp, D. J. (1971). Energy flow measurements. In: Holme, N. A., McIntyre, A. D. (ed.) Methods for the study of marine benthos. International Biological Programme Handbook No. 16. Blackwell, Oxford, p. 197-279

Dare, P. J. (1976). Settlement, growth and production of the mussel Mytilus edulis (L.) in Morecambe Bay, England. Fishery Invest., Lond. (Ser. II.), 28: 1-25

Dare, P. J., Edwards, D. B. (1975). Seasonal changes in flesh weight and biochemical composition of mussels (Mytilus edulis L.) in the Conway Estuary, North Wales. J. exp. mar. Biol. Ecol. 18: 89-97

Fox, D. L., Coe, W. R. (1943). Biology of the California seamussel (Mytilus californianus). II. Nutrition, metabolism, growth and calcium deposition. J. exp. Zool. 93: 205-249

Griffiths, C. L., King, J. A. (1979). Energy expended on growth and gonad output in the ribbed mussel Aulacomya ater. Mar. Biol. 53: 217-222

Harding, J. P. (1949). The use of probability paper for the graphical analysis of polymodal frequency distributions. J. mar. biol. Ass. U.K. 28: 141-153

Hawkins, A. J. S., Bayne, B. L. (1985). Seasonal variation in the relative utilization of carbon and nitrogen by the mussel Mytilus edulis: budgets, conversion efficiencies and maintenance requirements. Mar. Ecol. Prog. Ser. 25: $181-188$

Hawkins, A. J. S., Salkeld, P. N., Bayne, B. L., Gneiger, E., Lowe, D. M. (1985). Feeding and resource allocation in the mussel Mytilus edulis: evidence for time-averaged optimization. Mar. Ecol. Prog. Ser. 20: 273-287 
Jørgensen, C. B. (1976). Growth efficiencies and factors controlling size in small mytilid bivalves, especially Mytilus edulis L.: review and interpretation. Ophelia 15: 175-192

Kuenzler, E. J. (1961). Structure and energy flow of a mussel population in a Georgia salt marsh. Limnol. Oceanogr. 6: 191-204

Milne, H. A., Dunnet, G. M. (1972). Standing crop, productivity and trophic relations of the fauna of the Ythan estuary. In: Barnes, R. S. K., Green, J. (ed.) The estuarine environment. Associated Scientific Publishing, Amsterdam, p. $85-106$

Mossop, B. K. E. (1922). The rate of growth of the sea mussel (Mytilus edulis L.) at St. Andrews, New Brunswick; Digby, Nova Scotia; and in Hudson Bay. Trans. R. Can. Inst. 14: $3-22$

Newcombe, C. L. (1935). A study of the community relationships of the sea mussel Mytilus edulis (L.). Ecology 16: $234-243$

Paterson, C. G. (1982). Energy distribution in biomass estimates within a freshwater bivalve community. Can. J. Zool. 60: 2753-2756

Phillipson, J. (1964). A miniature bomb calorimeter for small biological samples. Oikos 15: 130-139

Reynolds, N. (1969). The settlement and survival of young mussels in the Conway fishery. Fishery Invest., Lond. (Ser. II), 26: 1-25

Ricker, W. E. (1975). Computation and interpretation of biological statistics for fish populations. Fish. Res. Bd Can. Bull. 191: 1-382

Seed, R. (1969). The ecology of Mytilus edulis (L.) (Lamellibranchiata) on exposed rocky shores. II. Growth and mortality. Oecologia (Berl.) 3: 317-350
Seed, R. (1973). Absolute and allometric growth in the mussel Mytilus edulis (L.) (Mollusca, Bivalvia), Proc. malac. Soc. Lond. 40: 343-357

Seed, R. (1980). Shell growth and form in the Bivalvia. In: Rhoads, D. C., Lutz, R. A. (ed.) Skeletal growth of aquatic organisms. Plenum Press, New York, p. 23-67

Stephenson, T. A., Stephenson, A. (1949). The universal features of zonation between tide-marks on rocky shores. J. Ecol. 37: 289-305

Suchanek, T H. (1978). The ecology of Mytilus edulis (L.) in exposed rocky intertidal communities. J. exp. mar. Biol. Ecol. 31: 105-120

Thomas, M. L. H., Arnold, D. C., Taylor, A. R. A. (1983). Rocky intertidal communities. In: Thomas, M. L. H. (ed.) Marine and coastal systems of the Quoddy Region, New Brunswick. Can. Spec. Publ. Fish. Aquat. Sci. 64: 35-73

Thompson, R. J. (1984). Production, reproductive effort, reproductive value and reproductive cost in a population of the blue mussel Mytilus edulis from a subarctic environment. Mar. Ecol. Prog. Ser. 16: 249-257

Wilbur, K. M., Saleuddin, A. S. M. (1983). Shell formation. In: Wilbur, K. M. (ed.) The mollusca, Vol. 4, Part 1. Academic Press, New York, p. 236-288

Wilbur, K. M., Yonge, C. M. (1964). Physiology of mollusca. Vol. 1 and 2. Academic Press, New York

Winberg, G. G. (1971). Methods for the estimation of production of aquatic animals. Academic Press, New York

Winter, J. E. (1976). Feeding experiments with Mytilus edulis at small laboratory scale. II. The influence of suspended silt in addition to algal suspensions on growth. Proceedings 10th European Symposium on Marine Biology, Vol. 1. Universa Press, Wetteren, p. 583-600 